\title{
The price of animal protein
}

\author{
Mass production of meat is on the rise, but it comes at a cost to both climate and environment. A radical \\ change in our diets seems to be the easiest path to long-term sustainability.
}

Livestock production has undergone a massive transformation in the past few decades. As meat demand has increased around the globe, small holdings and independent farms have been replaced with colossal corporate facilities, where animals are crammed into excrement-filled cages, and injected with antibiotics and hormones to maintain health and maximize growth. And with the United Nations Food and Agriculture Organization predicting that meat production will double by the middle of this century, conditions are set to worsen.

This is bad news for the planet. Animal manure is a rich source of nitrous oxide, the fourth most important greenhouse gas. An article on page 659 of this issue suggests that manure production has been a key driver of increasing nitrous oxide concentrations since 1860 . What's more, making animal feed releases large amounts of carbon dioxide, and the animals themselves, particularly cows, emit startling quantities of yet another greenhouse gas - methane.

The meat industry is also a catalyst for deforestation, particularly in South America. The film review on page 601 of this issue draws attention to the colossal speed at which the Amazon is being destroyed to make way for cattle and their feed. Making meat also requires huge quantities of antibiotics and hormones, which pollute the air and waterways. And intensive animal production units are hotbeds of disease transmission and viral evolution.

So what is the solution? One strategy is to regulate emissions. In Europe, the Gothenburg Protocol signed in
1999 - aimed at cutting harmful agricultural emissions - has proven to be a partial success (Nature Geosci. 1, 409-411; 2008). But regulating emissions from the meat industry on a global scale is an altogether different challenge; and cutting back on emissions would not necessarily help with deforestation, hormones, antibiotics or disease.

The real agent of change is the consumer, and tackling the problem from the bottom up, rather than from the top down, may prove to be the most effective remedy. If everyone were to eat less meat, emissions would go down, and the ecological damage wrought by this destructive industry would be lessened. This is the message championed by Rajendra Pachauri, the chairman of the Intergovernmental Panel on Climate Change. It is worth taking heed of.

\section{Depletion of the Indian well}

\section{The rapid draining of India's aquifers over the past six years warrants urgent attention.}

The Indian monsoon evokes images of torrential downpours and yearly flooding; indeed, some parts of the country receive more rain than any other region of the world. But most of this rainfall occurs during the summer months, and surface water sources are often ephemeral the rest of the year. No wonder then that many Indians turn to groundwater, be it for agriculture or for household use.

The fact that the nation's aquifers have been used and then overused over the past few decades was clear from the data compiled by Indian government agencies and nongovernmental organizations. What was not available was a quantitative assessment of the regional groundwater budget. Two independent studies have now provided an estimate of net groundwater loss using a satellite-based technique (Nature doi:10.1038/ nature08238; 2009 and Geophys. Res. Lett. doi:10.1029/2009GL039401; 2009). The results reveal that aquifers in northern India - the nation's most populous region with almost half a billion people - have been depleted at a mind-boggling rate.

Both studies used data obtained by NASA's Gravity Recovery and Climate Experiment
(GRACE) satellites that were launched in 2002. The results provide indisputable evidence that the rate of groundwater withdrawal was greater than the rate of recharge during the six years from 2002 to 2008. As a result, the region's aquifers lost almost $300 \mathrm{~km}^{3}$ of water - twice the volume of water in the Dead Sea and about one tenth of the annual rainfall over the whole of India. It does not take much to imagine that the country's large and growing population will put further pressure on its finite natural resources. But these figures are higher than official estimates and should serve as a definite wake-up call.

The Indian government does not have a strong track record in pre-empting looming disasters. The Indian public would therefore be forgiven for wondering whether the prospect of rapidly dwindling groundwater resources will serve as an impetus for prompt action. There is no paucity of sound advice regarding what needs to be done, however, and the government would do well to heed that.

Scientists and non-governmental organizations have long been advocating an intelligent, effective and equitable policy to manage water resources (for example, http://tinyurl.com/pu5adg). There is no question that available water should be used more efficiently with minimum wastage. Recharging aquifers by reducing runoff and facilitating percolation needs to be taken up with renewed vigour. Changes in the groundwater budget ought to be monitored at all levels, local as well as regional, and this information should be made accessible to consumers as well as policymakers.

India is the largest democracy in the world, something that its leaders and elite never tire of repeating. But regardless of the nation's adroitness in conducting general elections on a mammoth scale, it remains a sad fact that those who are likely to be most affected by a given issue often have the least say in it. Decreasing stocks of groundwater in northern Indian will undoubtedly have a disproportionate impact on the region's rural population and the urban poor.

India has thousands of voluntary organizations and millions of concerned citizens whose dedication and motivation are exemplary. Whether the various levels of government in India buck the trend and engage these stakeholders in a serious discussion remains to be seen. 